\title{
Sharing my problems soothed my headaches and took me out of loneliness
}

\author{
Berthilde Uwimbabazi
}

My name is Berthilde Uwimbabazi. I come from the Eastern Province, where I was born in 1960, one of 11 children of my farming parents. I married my husband in 1977. We had five children. When the genocide took place, it found us in Bugesera District. My parents, seven brothers and two of my sisters were all killed. Only one of my sisters and I escaped. However, I also lost my husband and four children. One child was killed by a neighbour. Of the children I had with my husband, I remained only with one - the one I carried on my back during the genocide. I also have another daughter as a result of the rape I experienced in 1998 and an adopted child.

I had a good life before the genocide. I was still healthy and my husband was working as a mason; we both had enough money as well as a large plot of agricultural land. My husband and I helped and understood each other. I liked my peers, my children, my neighbours and my friends, but most of them were killed during the genocide. I now live in a complex of newly built houses for poor and vulnerable people, inhabited by people from all over who do not know my sufferings. I sometimes feel intense sadness because they have called me Interahamwe. They were not in Rwanda during the genocide and have no idea about who I am. When I think about what happened to me during the genocide and about the way my neighbours talk about me, I feel intense sadness and grief so strong it kills me.

None of the previous conflicts in Rwanda were as violent as the 1994 genocide. After the airplane of President Habyarimana crashed, the Interahamwe started killing people that same night. My family and I took refuge at the Nyamata Catholic parish. After a few days, grenades and bombs were thrown into the church, killing or hurting those inside. Those who had been outside, including me, all ran away on their own without looking back. I went to hide in a nursery school. The same day we were shot at, MINUAR picked up the white French people who were staying there with us.

Three days later, the school guard chased out those who remained. I then started to hide in a forest during the daytime and slept in ruined houses during the nights. At one point the Interahamwe found me there with seven other women and young girls. From then on they raped us in turn in the evening after their daily work of killing Tutsis. We expected them to kill us too but they did not. Among the rapists were policemen and soldiers. I do not know whether they are still alive or not. I did not confront any rapist after the genocide. Nobody supported me during the genocide. Even the neighbour whom I once asked for drinking water in his home did not help me. Instead, his wife chased me away. I stayed in the wrecked houses until the Inkotanyi found me there.

After being saved by the Inkotanyi, I lived in Nyamata with many other survivors in the orphanage of Mengeti, run by a white Italian priest. Some of the survivors passed away because of cholera. After a few months, a female friend of mine came and took me to her home. We lived together from 1994 to 
1999. In 1998, when I was still living in her house, an unknown man came during the night, terrorized me and raped me. It was this rape which conceived the pregnancy of the last child I gave birth to.

A year later, I received a house in new social housing built for homeless people. I still live there with my two children, who do not have any aunt or uncle from their fathers' side, and my adopted child. All of my in-laws were killed in different places during the genocide, while my mother-in-law was killed together with my children in their hiding place. Regarding my own parents, my father had been murdered by Hutus in the 1959 massacres, and my mother was killed in our home area, Rwamagana, during the 1994 genocide.

The genocide rape seriously affected my health. As a consequence, I suffer from chronic back pain. In CHUCK, the University Teaching Hospital in Kigali, doctors told me that my uterus had moved from its place. For instance, when I lift something heavy I feel it prolapsing. My mental health was also damaged, and that is why I am always protecting myself against moral torture. Whenever I thought about my rape experiences, I felt insecure. I felt I had no heart in my belly and was always anxious. After the genocide I was always weeping, as my heart burst into tears and grief.

I endured many bad experiences: losing my children and my husband I loved so much, losing neighbours and staying alone on the hill, and living with people I did not know. However, nothing was as traumatic as being raped by strangers. When all of these things came together in my heart, I felt I was going to die for good and be forgotten.

When the genocide was over, people

a) This is a well-known expression in Kinyarwanda. It means having a feeling of insecurity and intense fear. would see me walking around, but I was not healthy at all. What increased my trauma were my neighbours' insults after I was elected president of the survivors in my area. Those insults started after I refused to enrol their non-survivor children on the list of FARG, which sponsors survivors. They were saying that I am Interahamwe like those who killed Tutsis. This insult made me feel intense sadness, and hate towards my neighbours filled my heart. I tried to hide my sorrow and I started to use waragi. I did not expect to survive much longer. I was always crying, living in depression. I was angry and liked to argue with people. I hated all men; I considered them wicked. The treatment I took for my ihahamuka was waragi. I became an alcoholic. My children used to buy it for me whenever I wanted it. Truly speaking, I did not think I would survive much longer.

As my back was very painful, the president of AVEGA from my hometown accompanied me to AVEGA's headquarters in Kigali, where they helped me get medical care at CHUK. The medicines I received decreased my back pain. However, until now I cannot cultivate or do any hard work, because when I bend down my uterus comes out. I have continued seeking medical care through FARG's mutual health insurance, but I still feel my uterus prolapsing when I work hard.

The genocide experiences continued to haunt me day and night until I consulted trauma counselling services. Before, my headaches were very severe, my heart was full of desperation and I felt hate for everybody, including my children. I was always taking medicines for headaches without any result. Day in, day out, I lived without hope for the future. After sharing my experiences with a friend of mine, who later became a lay counsellor of AVEGA, I felt my headaches improving. 
That friend referred me in 2002 to a trauma counsellor of Ibuka. The latter helped me to talk about the loss related to my genocide experiences. But I was not able to share the rapes I had endured with that counsellor because I found this story unspeakable. I felt ashamed. However, I became so sick due to rape-related consequences that for the first time I dared to share the experience with a nurse who had received me at AVEGA. For the second time, I shared it with my friend, the lay counsellor, because she had also been raped during the genocide. Before, I had kept this rape as my exclusive secret. Even those doctors who fixed my womb when I was at CHUK were not aware of my rape problem. But after speaking to the nurse I felt reassured somehow, largely due to the fact that she had informed me that I was HIV negative.

Regarding Gacaca courts, I participated in Gacaca several times as a witness. Gacaca calmed my heart somehow because I was testifying against the killers. No one whom I denounced denied my testimonies, because they knew I had seen them commit their crimes with my own eyes. However, I did not accuse anyone of raping me, because rape is not something to speak about publicly. I was frightened to talk about it in front of my children and afraid of being mocked by the audience. In addition, I do not know where those rapists are now hiding, so I did not see any reason to expose myself in Gacaca for nothing.

One positive thing that came out of Gacaca is that it helped survivors find where the remaining bodies of their lost relatives were thrown. Another thing is that it punished the perpetrators who were there. However, there are other things that were not solved by Gacaca as they had been expected to, because of some of the Gacaca judges' ill will. ${ }^{\mathrm{b}}$ Therefore, the truth expected from
Gacaca courts was not fully told. In addition, I noticed that Gacaca was given too short a time, because it stopped its activities before some people, including myself, could find out where their relatives had been thrown. Those who killed them kept quiet; they did not want to tell the truth. Personally, I feel justice has not been done completely because Gacaca did not finish all trial cases. Laws were put in place, but were not all respected. For instance, Gacaca did not judge those who looted properties, or those who destroyed the house of my parents. So, personally, I would like them to finish all cases.

Gacaca did not traumatize me. On the contrary, it healed me from trauma. It allowed my neighbours who used to say that I am Interahamwe and that my brothers are imprisoned in Ririma prison to learn that I am not as they perceived me. Gacaca was an answer to them. After the commencement of Gacaca, they did not repeat bad words to me anymore. But still, I cannot say anything about reconciliation, because I did not see anybody come to apologize.

Because I was known as a person who experienced problems, I was invited in 2010 by my friend, the lay counsellor, to join the sociotherapy programme. But the first time I refused, because I did not give any value to her invitation. She continued to tell me about it until I accepted to join. After participating in sociotherapy, I liked it. Before I joined sociotherapy, I was always afraid, but soon after I joined it I felt free because all of the women had the same problems. Before sociotherapy, I was living in isolation. I thought that I was the only one who had experienced rape. Sociotherapy helped me to talk about my problems, and as a result, after sharing my story, my head

\footnotetext{
b) Local people call these judges 'people of integrity' or 'integrates'.
} 
recovered. During sociotherapy, the hate I felt towards my children and my neighbours disappeared.

What I liked in sociotherapy is that we tell the truth to each other. During the tenth session of sociotherapy, I shared my bad experiences with other women in the group. Before sharing my story, I was worried and had no security in my heart, because I was afraid that members of the group might tell my story to my children. When I finally spoke, I was sad and full of emotions. I cried and others helped me to cry. After I had finished talking, I felt relieved. My headaches are gone. Since then I do not need any painkillers anymore.

Since a few days after the genocide, I had long suffered from recurring ihahamuka with excessive anger, especially during the three months of genocide commemoration. I cried throughout this period, from the first day to the last. I tried not to miss any commemoration ceremony and followed all programmes on the radio. I am thrilled because I no longer suffer from ihahamuka since I completed the fifteen sociotherapy sessions, also not during the last commemoration period (in 2012).

Meeting other women in sociotherapy took me out of loneliness. As a result, my relationship with others changed. Before, I hated my children. I used to beat them whenever they tried to speak with me. Regarding my neighbours, I did not feel free with them because they have their children and families, but today I talk to them. I was living alone, but now they visit me as I visit them. I now consider them my relatives, which is different from before. Before I spoke in sociotherapy, I felt I had no value. I felt like I was an object, not like a human being. I feel I am now a human being like others.

Even though I do not have anyone to support me, participating in sociotherapy brought me hope for the future. I planned a small project of cultivating a lawn, which may help me earn a living. I also cultivate bananas. I expect my projects to succeed, because I have been healed. And I hope the goat I received from sociotherapy will in the due course of time help me to earn money so that I can satisfy some needs at home.

I believe that in the future my children will finish their studies. However, I am always wondering where I will find school fees for my lastborn conceived during the second rape. FARG will not pay for her because she is not a survivor. After being refused by FARG, she will ask me why they will not sponsor her. What will I tell her? This is a big problem I have.

Another thing that worries me is that there is a person who wants to take my parents' land in Rwamagana by force. I am saddened by being poor. Being poor, I do not have enough money for transportation, so that I cannot regularly follow the progress of our trial. However, aside from my worries, I am a changed person now, one who is willing to help others.

I would advise all women who experienced problems similar to mine to withstand them. I encourage them to pray for each other and then meet together in order to comfort each other and get out of loneliness. I wish that everybody who will hear my story and learn how I was healed will also get out of their grief. 